\title{
Processing of Boron Carbide-Aluminum Composites
}

\author{
Danny C. Halverson* \\ Lawrence Livermore National Laboratory, University of California, Livermore, California 94550 \\ Aleksander J. Pyzik* and Ilhan A. Aksay* \\ Department of Materials Science and Engineering, University of Washington, \\ Seattle. Washington 98195 \\ William E. Snowden ${ }^{\star * *}$ \\ Lawrence Livermore National Laboratory, University of California, Livermore, California 94550
}

\begin{abstract}
The processing problems associated with boron carbide and the limitations of its mechanical properties can be significantly reduced when a metal phase (e.g., aluminum) is added. Lower densification temperatures and higher fracture toughness will result. Based on fundamental capillarity thermodynamics, reaction thermodynamics, and densification kinetics, we have established reliable criteria for fabricating $B_{4} \mathrm{C}-\mathrm{Al}$ particulate composites. Because chemical reactions cannot be eliminated, it is necessary to process $\mathrm{B}_{4} \mathrm{C}-\mathrm{Al}$ by rapidly heating to near $1200^{\circ} \mathrm{C}$ (to ensure wetting) and subsequently heat-treating below $1200^{\circ} \mathrm{C}$ (for microstructural development). [Key words: composites, boron carbide, aluminum, processing, cermets.]
\end{abstract}

\section{Introduction}

B ORON CARBIDE $\left(\mathrm{B}_{4} \mathrm{C}\right)^{\dagger}$ is a very hard $\left(9.5+\right.$ in Mohs scale) ${ }^{1}$ low specific gravity $(2.52)$, covalent ceramic that offers distinct advantages for applications involving neutron absorption, wear resistance, and impact resistance. The extreme sensitivity of $\mathrm{B}_{4} \mathrm{C}$ to brittle fracture $\left(K_{1 \mathrm{c}}=3.7 \mathrm{MPa} \cdot \mathrm{m}^{1 / 2}\right)^{2}$ and the difficulties associated with fabricating fully dense microstructures are serious limitations, however. By using certain additives (e.g., graphite), $\mathrm{B}_{4} \mathrm{C}$ sintered at high temperatures $\left(>2000^{\circ} \mathrm{C}\right)$ can produce microstructures with a high density $(\approx 98.2 \%$ of theoretical density). ${ }^{3}$ Full density is usually achieved through costly hotpressing techniques; ${ }^{4}$ however, even in a fully dense form, the sensitivity of boron carbide to brittle fracture remains a major limitation.

Our experiments demonstrated that the processing problems and mechanical property limitations associated with $\mathrm{B}_{4} \mathrm{C}$ ceramics can be significantly reduced by introducing a metal phase (i.e., by developing $\mathrm{B}_{4} \mathrm{C}$ cermets). If the application is limited to low temperatures, then a low-melting-point metal phase (e.g., aluminum or aluminum alloys) can be introduced to obtain lower densification temperatures $\left(<1200^{\circ} \mathrm{C}\right)$ and to increase fracture toughness many times that of $\mathrm{B}_{4} \mathrm{C}$. In addition, if the metal phase

J. J. Petrovic-contributing editor

Manuscript No. 199146. Received November 19, 1986; approved September 2, 1988

Supported by the U.S. Department of Energy at Lawrence Livermore National Laboratory under Contract No. W-7504-ENG-48 and by the U.S. Air Force Office of Scientific Research under Grant No. AFOSR-83-0375 at the University of of Scientific

"Member, American Ceramic Society.

*Now with the Office of the Director of Defense Research and Engineering, The Pentagon, Washington, DC 20301

$\mathrm{B}_{4} \mathrm{C}$ herein refers to the complete homogeneous range of compositions for boron carbide.

${ }^{8}$ ESK, GmbH, Munchen, FRG

"Alfa Products. Danvers. MA. has a low specific gravity, then the resulting cermet can have improved mechanical properties with low weight.

High-strength (>1000 MPa) B-C-Al composites consisting of $\mathrm{B}_{4} \mathrm{C}$-coated boron fibers in an aluminum matrix $(\approx 50$ vol\% ceramic) have been fabricated. ${ }^{5}$ Particulate $\mathrm{B}_{4} \mathrm{C}$-metal composites currently manufactured include materials consisting of dispersion-hardened metals $\left(\leq 25\right.$ vol $\left.\% \mathrm{~B}_{4} \mathrm{C}\right),{ }^{1,6}$ boral (30 to 50 vol\% $\left.\mathrm{B}_{4} \mathrm{C}\right),{ }^{7}$ and $\mathrm{B}_{4} \mathrm{C}-\mathrm{Cu}$ cermets $\left(\approx 60\right.$ vol\% $\left.\mathrm{B}_{4} \mathrm{C}\right) .{ }^{8}$ In these composites, processing temperatures are kept to a minimum $\left(<1000^{\circ} \mathrm{C}\right)$, primarily to avoid chemical reactions between $\mathrm{B}_{4} \mathrm{C}$ and the metal phase.

In our work with particulate $\mathrm{B}_{4} \mathrm{C}-\mathrm{Al}$ composites which have a greater ceramic content ( $>55$ vol\%), we employed processing temperatures above $1000^{\circ} \mathrm{C}$ to promote wetting and to permit carefully controlled reactions in the system. Wetting is necessary to achieve strong interfacial bonding and to allow liquid rearrangement during sintering. If wetting does not occur, external pressure must be applied to improve consolidation; however, even pressure techniques are not satisfactory for densification of some high-ceramic-containing ( $>60$ vol\%) composites. ${ }^{8}$

We illustrate in this paper the importance of achieving a wetting condition in the processing of high ceramic content $\left(>55\right.$ vol\%), particulate-based $\mathrm{B}_{4} \mathrm{C}-\mathrm{Al}$ composites, the importance of understanding the phase equilibria in the B-C-Al system for the microstructural design of these cermets, and appropriate processing methods for producing cermets with negligible porosity.

\section{Processing Experiments}

\section{(1) Materials and Specimen Preparation}

We used sessile drops formed from high-purity aluminum shot $\left(99.999 \%\right.$ pure), hot-pressed $\mathrm{B}_{4} \mathrm{C}$ substrates made from commercial-grade $\mathrm{B}_{4} \mathrm{C}$ powders, and $\mathrm{B}_{4} \mathrm{C}-\mathrm{Al}$ compacts made from commercial-grade $\mathrm{B}_{4} \mathrm{C}$ and aluminum powders. Compacts were small, generally $2.54 \mathrm{~cm}$ in diameter and 0.32 to $0.64 \mathrm{~cm}$ thick.

To prepare these compacts, we mixed $\mathrm{B}_{4} \mathrm{C}$ powder ${ }^{8}$ (three particle-size distributions with median sizes of 4,10 , and $56 \mu \mathrm{m}$ ) and aluminum powder" $(-325$ mesh) in isopropyl alcohol, ultrasonically mixed the slurry to achieve homogeneity, and consolidated the solids by filtration in a plaster-of-Paris mold. These compacts were too weak for handling purposes; therefore, the composite powders were subsequently cold-pressed at $138 \mathrm{MPa}$ $(\approx 20000 \mathrm{psi})$. We found that higher pressures resulted in undesirable striations in the compacts.

\section{(2) Procedures}

Our processing experiments included contact-angle measurements, chemical reaction studies, and densification studies in the molten aluminum- $\mathrm{B}_{4} \mathrm{C}$ system.

In conducting our contact-angles experiments, we placed alu- 
Table I. Vacuum-Hot-Pressed $\mathrm{B}_{\mathbf{4}} \mathrm{C}-\mathrm{Al}$ Densification Results*

\begin{tabular}{ccccc}
\hline $\begin{array}{c}\text { Aluminum } \\
\text { content } \\
(\text { vol\%) }\end{array}$ & $\begin{array}{c}\mathrm{B}_{4} \mathrm{C} \\
\text { grain size } \\
(\mu \mathrm{m})\end{array}$ & $\begin{array}{c}\text { Maximum } \\
\text { temperature } \\
\left({ }^{\circ} \mathrm{C}\right)\end{array}$ & $\begin{array}{c}\text { Indicated } \\
\text { pressure } \\
(\mathrm{MPa})\end{array}$ & $\begin{array}{c}\text { Residual } \\
\text { compact porosity } \\
(\text { vol\%) }\end{array}$ \\
\hline 30 & $<2$ & 1180 & 15 & 24 \\
50 & $<2$ & 1180 & 15 & 8 \\
50 & $<2$ & 1050 & 20 & 14 \\
50 & $<20$ & 1150 & 15 & 22 \\
60 & $<20$ & 1100 & 15 & 13 \\
\hline
\end{tabular}

*All runs took $75 \mathrm{~min}$ to reach maximum temperature. Maximum temperature hold time was $6 \mathrm{~min}$ at the indicated pressure with pressure being applied after passing through $800^{\circ} \mathrm{C}$. Processing environment was $\approx 5 \times 10^{-2} \mathrm{~Pa}\left(10^{-3}\right.$ to $10^{-4}$ torr) Samples were furnace cooled in vacuum under the indicated pressure. Porosity was determined by bulk density measurements.

Table II. Hot Isostatic Pressed $\mathrm{B}_{4} \mathrm{C}-\mathrm{Al}$ Densification Results*

\begin{tabular}{ccccc}
\hline $\begin{array}{c}\text { Aluminum } \\
\text { content } \\
(\text { vol\%) }\end{array}$ & $\begin{array}{c}\mathrm{B}_{4} \mathrm{C} \text { average } \\
\text { grain size } \\
(\mu \mathrm{m})\end{array}$ & $\begin{array}{c}\text { Maximum } \\
\text { temperature } \\
\left({ }^{\circ} \mathrm{C}\right)\end{array}$ & $\begin{array}{c}\text { Sample } \\
\text { presintered }\end{array}$ & $\begin{array}{c}\text { Residual } \\
\text { connected porosity } \\
(\text { vol\%) }\end{array}$ \\
\hline 15 & 55 & 1000 & Yes & 3.50 \\
30 & 55 & 1000 & Yes & 0.11 \\
45 & 55 & 1000 & Yes & 0.04 \\
30 & 4 & 750 & No & $>10$ \\
\hline
\end{tabular}

*All samples were run at the maximum temperature with a 30 -min hold at $207-\mathrm{MPa}$ argon. Heating and cooling rates of $50^{\circ} \mathrm{C} / \mathrm{min}$ were used at $207 \mathrm{MPa}$ Porosity was determined by immersion density measurements after 5 min. ${ }^{t} 1180^{\circ} \mathrm{C}$ for 2 min at $\approx 10^{-3} \mathrm{~Pa}$.

minum sessile drops on hot-pressed $\mathrm{B}_{4} \mathrm{C}$ substrates (polished to a $1-\mu \mathrm{m}$ finish) and heated them in a tungsten-mesh, resistanceheated vacuum furnace at pressures less than $5 \times 10^{-3} \mathrm{~Pa}$ but greater than $10^{-4} \mathrm{~Pa}$ (typically between $10^{-5}$ and $10^{-6}$ torr). After the specimens were vacuum cooled to room temperature and taken out of the furnace, we measured the contact angles to within $1^{\circ}$ using a protractor grid and optical $10 \times$ telemicroscope.

To investigate the nature and extent of the chemical reactions at the $\mathrm{B}_{4} \mathrm{C}-\mathrm{Al}$ interface, we examined polished (1- $\mu \mathrm{m}$ finish) cross sections of specimens from the wetting experiments using both optical and scanning electron microscopes. Further studies included X-ray diffraction (XRD), energy dispersive spectros-

**Model 200 ( 2.0 centistrokes), Dow Corning Corp., Midland, MI.

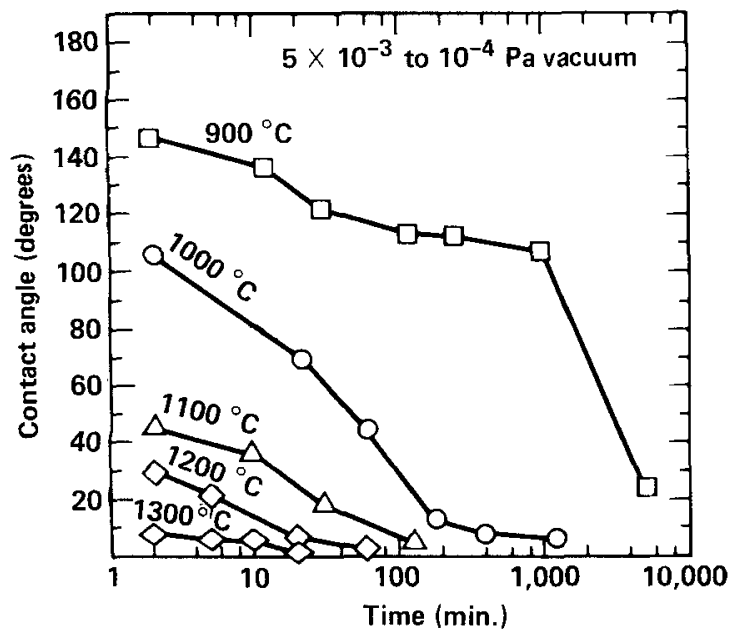

Fig. 1. Contact angle of molten aluminum on $\mathrm{B}_{4} \mathrm{C}$ as a function of processing time for various isotherms at $5 \times 10^{-3}$ to $1 \times 10^{-4} \mathrm{~Pa}$. Measurements were obtained after sessile drop was furnace cooled to room temperature. copy, and electron microprobe analyses to identify the reaction products in the microstructures of the sintered compacts.

In our densification kinetics studies, we subjected the $\mathrm{B}_{4} \mathrm{C}-\mathrm{Al}$ powder compacts to pressureless sintering, hot-pressing, and hot isostatic pressing. We sintered specimens in the tungsten-mesh, resistance-heated vacuum furnace at the same pressures used in the sessile-drop experiments. Hot-pressing and hot isostatic pressing were performed in accordance with the processing information in Tables I and II. Some hot isostatically pressed samples were presintered because they were processed at temperatures lower than those required for adequate wetting. To determine the level of residual porosity, we made immersion density** and bulk density measurements on each compact.

Weight loss due to evaporization of aluminum was not measured. Weight loss was evident, however, because furnace contamination was observed. Weight-loss measurements would be difficult because many phases are forming with different theoretical densities.

\section{Results and Discussion}

\section{(1) Wetting}

An important point to be realized is that a nonwetting system can be transformed to a wetting system by taking advantage of chemical reactions. ${ }^{9}$ Previous studies on the $\mathrm{B}_{4} \mathrm{C}-\mathrm{Al}$ system did not correctly recognize this fact, and, as a result, both obtuse $\mathrm{e}^{10,11}$ and acute $\mathrm{e}^{11-14}$ contact angles were reported as equilibrium values. Previous works ${ }^{10.15}$ on $\mathrm{B}_{4} \mathrm{C}-\mathrm{Al}$ composites were discontinued when it was concluded that aluminum did not wet $\mathrm{B}_{4} \mathrm{C}$.

Figure 1 shows the contact angle of aluminum on $\mathrm{B}_{4} \mathrm{C}$ as a function of temperature and time. Based on our contact-angle data, processing of $\mathrm{B}_{4} \mathrm{C}-\mathrm{Al}$ composites below $1000^{\circ} \mathrm{C}$ cannot be accomplished by pressureless sintering techniques because acute contact angles are not obtained in reasonably short times. By increasing the temperature, low contact angles are obtained in reasonably short times; however, because the vapor pressure of aluminum also increases with increasing temperature, an upper processing temperature limit is also necessary to keep vaporization of the aluminum to a minimum.

The dynamic nature of the contact angle of aluminum on $\mathrm{B}_{4} \mathrm{C}$ is associated with the mass transfer across the solid-liquid interface as the system moves toward a state of chemical equilibrium. During this dynamic stage, the contact angle cannot be expected to remain constant because the interfacial tensions between the solid, liquid, and vapor phases will be continuously changing as a result of compositional and structural variations across the interfaces. The nature of these reactions will be discussed in the next section.

\section{(2) Reaction Thermodynamics}

At least nine ternary phases have been reported for the B-C-Al system; ${ }^{16-28}$ consequently, it is important to select processing conditions that will allow only certain reaction products to form so that desired properties (negligible $\mathrm{Al}_{4} \mathrm{C}_{3}$ ) will be obtained. Previous attempts ${ }^{29}$ to fabricate $\mathrm{B}_{4} \mathrm{C}-\mathrm{Al}$ cermets were discontinued when it was concluded that the reaction products were detrimental to mechanical properties.

We investigated the reaction products that occur under different sets of wetting conditions. Figure 2 illustrates the results of our reaction thermodynamic studies from $800^{\circ}$ to $1400^{\circ} \mathrm{C}$ and the reaction products that form when local equilibrium conditions are achieved. Under these conditions, sufficient aluminum is present to sustain the reactions shown. For any starting composition, the initial reaction products will always form at the expense of $\mathrm{B}_{4} \mathrm{C}$ and aluminum.

Figure 3 shows some of the characteristic microstrustures that can be obtained under conditions of local equilibrium. An unidentified phase, called phase $X$, forms at all of the temperatures in this study. Phase $\mathrm{X}$ can coexist with $\mathrm{B}_{4} \mathrm{C}$. Initial attempts to identify phase $X$ were unsuccessful because its XRD pattern did not match any binary $\mathrm{Al}_{x} \mathrm{~B}_{y}, \mathrm{Al}_{x} \mathrm{C}_{y}, \mathrm{~B}_{x} \mathrm{C}_{y}$; ternary $\mathrm{Al}_{x} \mathrm{~B}_{y} \mathrm{C}_{z}$; or binary or ternary oxide, nitride, oxycarbide, oxynitride, or car- 
Fig. 2. Thermodynamic-reactionseries map for $\mathrm{B}_{4} \mathrm{C}-\mathrm{Al}$ composites initially densified at $1180^{\circ} \mathrm{C}$ and heat-treated under various isothermal conditions between $800^{\circ}$ and $1400^{\circ} \mathrm{C}$.

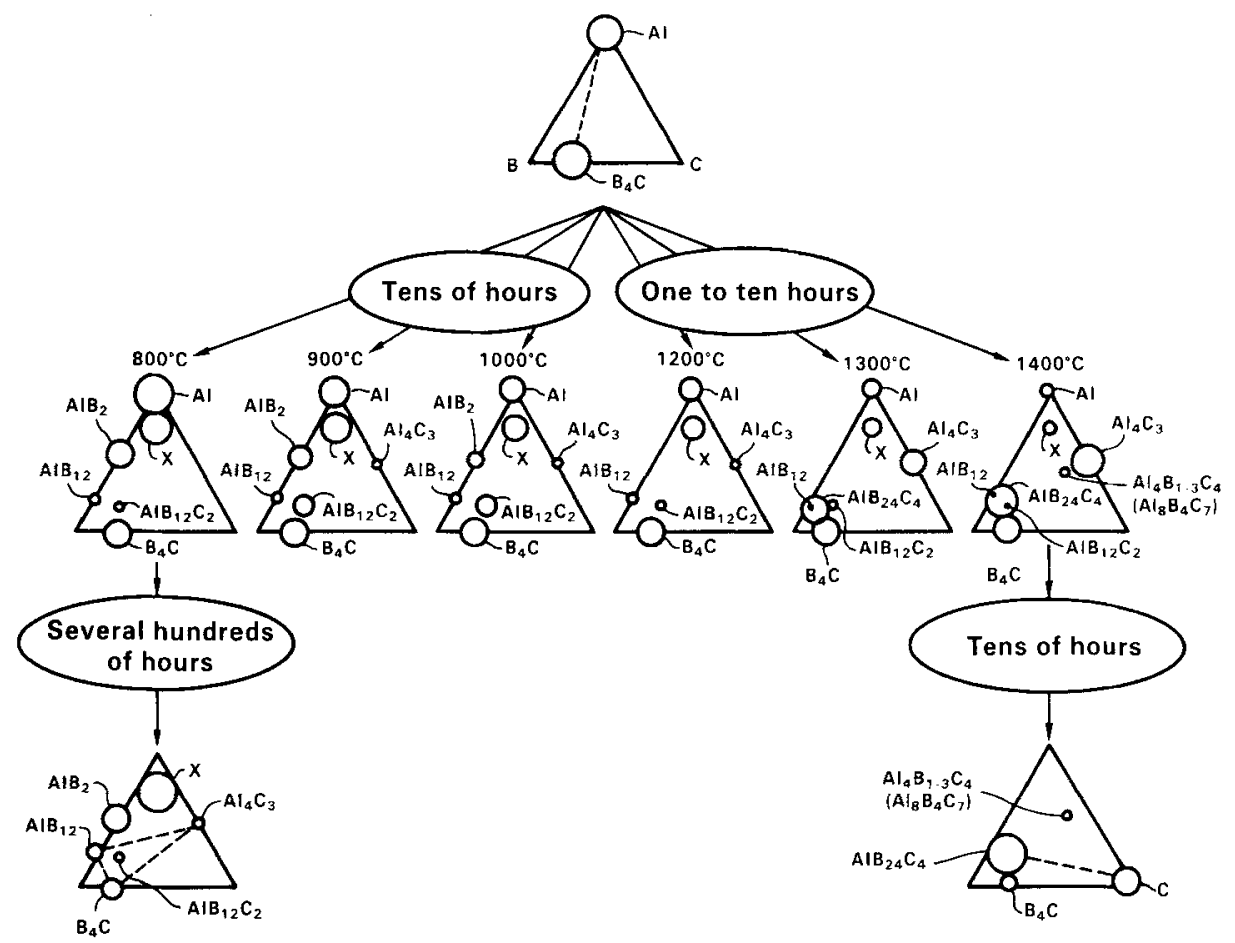

bonitride XRD patterns. ${ }^{30}$ Some of the characteristic XRD lines for phase $X$ have been recently reported, ${ }^{31}$ and energy dispersive $\mathrm{X}$-ray and electron microprobe analyses indicate that phase $\mathrm{X}$ is largely aluminum with smaller amounts of boron and carbon.

In a recent study, Sarikaya et al. ${ }^{32}$ characterized the crystal structure and composition of phase $\mathrm{X}$ by transmission electron microscopy techniques. Electron diffraction studies indicate that the crystal structure of phase $\mathrm{X}$ is hexagonal close packed with lattice parameters quite different from any of the other binary or ternary phases in the B-C-Al system. Their preliminary studies by electron energy loss spectroscopy indicate that the composition of phase $\mathrm{X}$ is $\mathrm{Al}_{4} \mathrm{BC}$.

$\mathrm{B}_{4} \mathrm{C}$ and aluminum react to form phase $\mathrm{X}$. Under local equilibrium between $800^{\circ}$ and $900^{\circ} \mathrm{C}, \mathrm{AlB}_{2}$ and phase $\mathrm{X}$ are the major reaction products. Under these conditions, phase $X$ is stable, and it will decompose only after all of the free aluminum is depleted from the system. Above $1100^{\circ} \mathrm{C}$, there is less phase $\mathrm{X}$ because aluminum is rapidly being depleted through the formation of other more thermodynamically stable phases.

Figure 3(A) shows a typical microstructure in local equilibrium
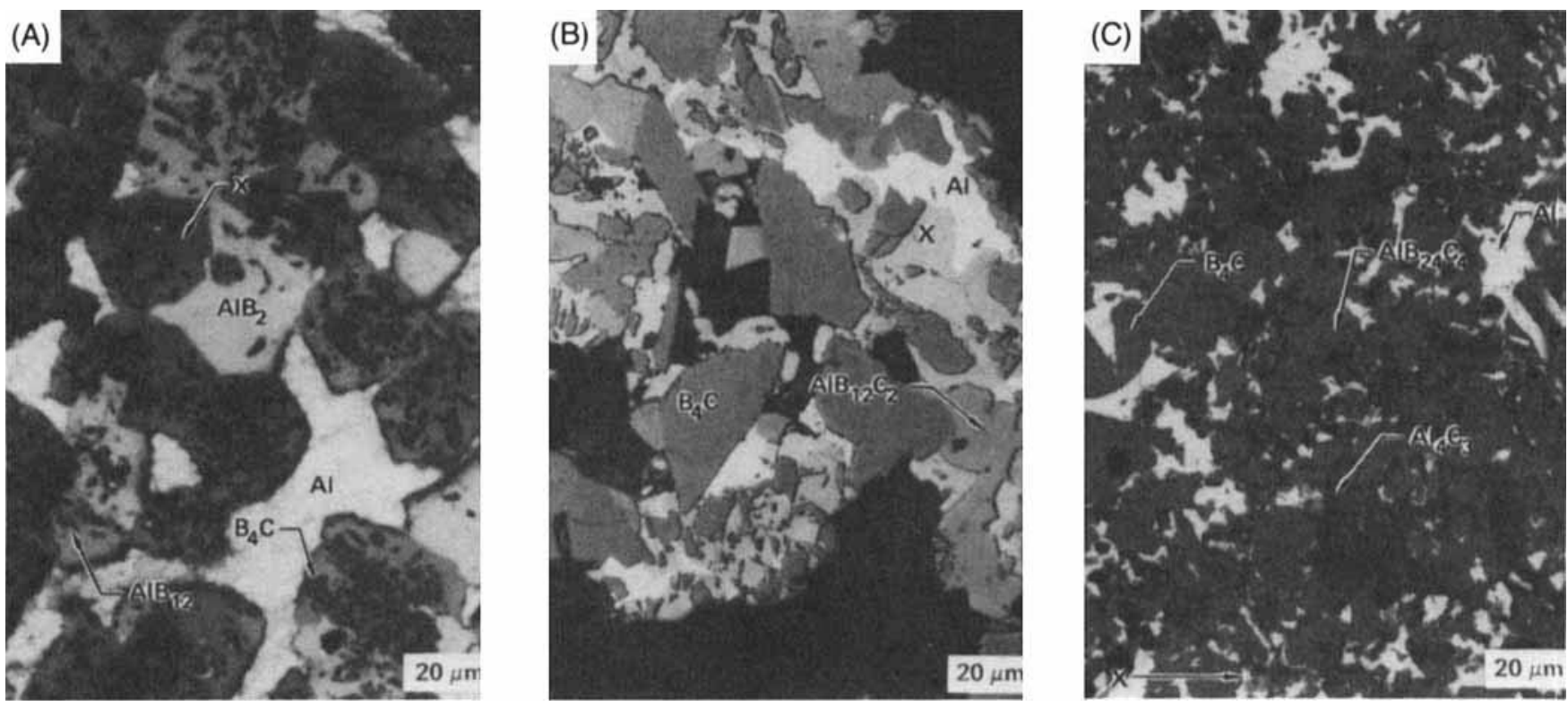

Fig. 3. $\mathrm{B}_{4} \mathrm{C}-\mathrm{Al}$ cermets showing different sintered microstructures obtained after initially heating to $1180^{\circ} \mathrm{C}$ for 2 min and subsequently heat-treating at (A) $800^{\circ} \mathrm{C}$ for $24 \mathrm{~h}$ (initial composition: 80 vol\% $\mathrm{B}_{4} \mathrm{C}-20$ vol\% $\mathrm{Al}$ ); (B) $1000^{\circ} \mathrm{C}$ for $1.5 \mathrm{~h}$ (initial composition: 70 vol\% $\mathrm{B}_{4} \mathrm{C}-30$ vol\% $\mathrm{Al}$ ); and (C) $1300^{\circ} \mathrm{C}$ for $1 \mathrm{~h}$ (initial composition: 30 vol\% $\mathrm{B}_{4} \mathrm{C}-70$ vol\% Al). 
at $800^{\circ}$ to $900^{\circ} \mathrm{C}$. Small grains $\left(1\right.$ to $5 \mu \mathrm{m}$ ) of $\mathrm{B}_{4} \mathrm{C}$ are surrounded by large, forming ceramic phases. After $24 \mathrm{~h}$ of heat treatment at $800^{\circ} \mathrm{C}$ (Fig. $3(\mathrm{~A})$ ), there is more phase $\mathrm{X}$ and $\mathrm{AlB}_{2}$ than $\mathrm{B}_{4} \mathrm{C}$ (initial composition: $80 \mathrm{vol} \% \mathrm{~B}_{4} \mathrm{C}-20 \mathrm{vol} \% \mathrm{Al}$ ). This microstructure reaches local equilibrium between phase $\mathrm{X}, \mathrm{AlB}_{2}$, and $\mathrm{B}_{4} \mathrm{C}$ within tens of hours at $800^{\circ} \mathrm{C}$. After $250 \mathrm{~h}$, the amount of $\mathrm{AlB}_{2}$ has decreased to form $\mathrm{AlB}_{12}$; after $500 \mathrm{~h}, \mathrm{~B}_{4} \mathrm{C}$, phase $\mathrm{X}, \mathrm{AlB}_{2}$, $\mathrm{AlB}_{12} \mathrm{C}_{2}$, and $\mathrm{Al}_{4} \mathrm{C}_{3}$ are substantially present in the microstructure. Further heat treatment indicates a tendency to the rapid depletion of phase $\mathrm{X}$ and an increase of $\mathrm{AlB}_{12}$ and $\mathrm{Al}_{4} \mathrm{C}_{3}$.

The hypothetical compatibility triangle shown in the lower lefthand corner of Fig. 2 illustrates the tendency toward overall thermodynamic equilibrium. It is assumed that overall equilibrium is achieved when $\mathrm{AlB}_{12}, \mathrm{Al}_{4} \mathrm{C}_{3}$, and $\mathrm{B}_{4} \mathrm{C}$ coexist as stable phases.

Above $900^{\circ} \mathrm{C}$, but below $1200^{\circ} \mathrm{C}$, the following microstructural differences occur: (1) $\mathrm{AlB}_{12} \mathrm{C}_{2}$ is thermodynamically favored over $\mathrm{AlB}_{12}$ between $900^{\circ}$ and $1000^{\circ} \mathrm{C}$, and (2) $\mathrm{AlB}_{2}$ continues to form up to $1000^{\circ} \mathrm{C}$; however, above $1000^{\circ} \mathrm{C}, \mathrm{AlB}_{2}$ is only present when the microstructure is cooled. Figure $3(\mathrm{~B})$ shows a microstructure resulting from these local equilibrium conditions after $1.5 \mathrm{~h}$ at $1000^{\circ} \mathrm{C}$ (initial composition: 70 vol\% $\mathrm{B}_{4} \mathrm{C}-30$ vol\% $\mathrm{Al}$ ).

Between $1200^{\circ}$ and $1400^{\circ} \mathrm{C}$, the following further changes in the microstructure occur: (1) $\mathrm{Al}_{4} \mathrm{C}_{3}$ is forming very quickly (associated with a decrease of the ternary phase $\mathrm{X}$ ); (2) $\mathrm{AlB}_{24} \mathrm{C}_{4}$ is now favored over $\mathrm{AlB}_{12} \mathrm{C}_{2}$ and becomes the major ternary phase; (3) above $1300^{\circ} \mathrm{C}, \mathrm{XRD}$ patterns indicate the appearance of a phase previously reported as $\mathrm{Al}_{4} \mathrm{~B}_{1-3} \mathrm{C}_{4},{ }^{17}$ but more recently reported as $\mathrm{Al}_{8} \mathrm{~B}_{4} \mathrm{C}_{7},{ }^{28}$ and (4) at $1400^{\circ} \mathrm{C}, \mathrm{Al}_{4} \mathrm{C}_{3}$ begins to crystallize in the shape of short whiskers. Figure $3(\mathrm{C})$ shows a microstructure characteristic of the local equilibrium conditions after $1 \mathrm{~h}$ at $1300^{\circ} \mathrm{C}$ (initial composition: 30 vol\% $\mathrm{B}_{4} \mathrm{C}-70 \mathrm{vol} \% \mathrm{Al}$ ).

At temperatures above $1300^{\circ} \mathrm{C}$, overall equilibrium occurs only after all aluminum and phase $\mathrm{X}$ are completely depleted from the system. This is followed by the decomposition of $\mathrm{Al}_{4} \mathrm{C}_{3}$ and the eventual coexistence of graphite, $B_{4} C$, and $A I B_{24} C_{4}$ as the remaining stable phases. The compatibility triangle in the lower righthand corner of Fig. 2 illustrates this global equilibrium condition.

Our reaction thermodynamic study determined that local equilibrium conditions between $800^{\circ}$ and $1200^{\circ} \mathrm{C}$ must be established so that phase $\mathrm{X}$ will evolve and consequently tie up most of the free carbon required to form $\mathrm{Al}_{4} \mathrm{C}_{3}$. Because of its hygroscopic nature and poor mechanical properties, $\mathrm{Al}_{4} \mathrm{C}_{3}$ is undesirable. Above $1200^{\circ} \mathrm{C}$, local equilibrium conditions do not suppress

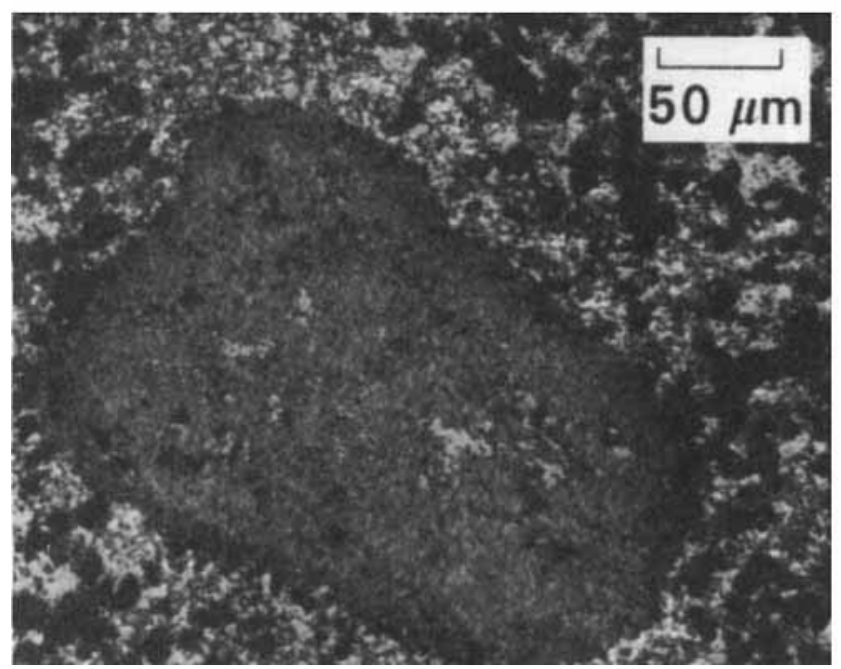

Fig. 4. $\mathrm{B}_{4} \mathrm{C}-\mathrm{Al}\left(30\right.$ vol\%) cermet hot-pressed at $1180^{\circ} \mathrm{C}$ under vacuum $\left(5 \times 10^{-2} \mathrm{~Pa}\right)$ for $6 \mathrm{~min}$ at $15 \mathrm{MPa}(\approx 2000 \mathrm{psi})$ showing a region of local densifjcation surrounded by porous regions.
$\mathrm{Al}_{4} \mathrm{C}_{3}$ formation; however, composites with $\mathrm{Al}_{4} \mathrm{C}_{3}$ whiskers are more chemically stable because of a protective layer of phase $\mathrm{X}$ around them. Therefore, to process $\mathrm{B}_{4} \mathrm{C}-\mathrm{Al}$ cermets, it is necessary to rapidly heat the composition to near $1200^{\circ} \mathrm{C}$ to ensure that wetting occurs and subsequently heat-treat these compositions at temperatures below $1200^{\circ} \mathrm{C}$ if further microstructural development is desired.

\section{(3) Densification Kinetics}

Fully dense states can be achieved prior to reaching desired thermodynamic conditions either by slowing down reaction kinetics or by speeding up densification kinetics. Favorable results can be obtained by employing small-size powders; however, in our study, the larger $\mathrm{B}_{4} \mathrm{C}$ powders $(56 \mu \mathrm{m})$ were primarily used for two reasons. First, because appropriate colloidal processing techniques for codispersing $\mathrm{B}_{4} \mathrm{C}$ and aluminum powders had not yet been developed, the $4-$ and $10-\mu \mathrm{m} \mathrm{B}_{4} \mathrm{C}$ powders resulted in large agglomerates $(250 \mu \mathrm{m})$ which led to microstructural inhomogeneities during sintering. Second, we wanted to show that $\mathrm{B}_{4} \mathrm{C}-\mathrm{Al}$ composites could be fabricated without agglomeration problems and at the same time reduce the rate of chemical reactions by decreasing the $\mathrm{B}_{4} \mathrm{C}-\mathrm{Al}$ interfacial area.

The starting $\mathrm{B}_{4} \mathrm{C}$ particle size did not affect the cold-pressed $\mathrm{B}_{4} \mathrm{C}-\mathrm{Al}$ green density. All three particle sizes result in producing $\approx 65 \%$ dense green parts with 30 vol\% aluminum content and $\approx 72 \%$ dense green parts with $50 \mathrm{vol} \%$ aluminum content.

$\mathrm{B}_{4} \mathrm{C}$-aluminum compacts will undergo neither pressureless nor pressure-assisted densification unless wetting occurs. Our pressureless sintered compacts always had residual porosity from $28 \mathrm{vol} \%$ (for compacts containing 30 to $45 \mathrm{vol} \%$ aluminum) to as high as 44 vol\% (for compacts containing 15 to 30 vol\% aluminum). This occurred despite the fact that conditions for wetting were obtained; however, compacts with larger $\mathrm{B}_{4} \mathrm{C}$ particles $(56 \mu \mathrm{m})$ did achieve slightly higher densities than compacts with smaller $\mathrm{B}_{4} \mathrm{C}$ particles ( 4 and $10 \mu \mathrm{m}$ ). In all cases, compact sintered densities were about $5 \%$ lower than their initial green densities. Even when pressure techniques (vacuum hot-pressing and hot isostatic pressing) were applied to compacts containing be tween 15 and $60 \mathrm{vol} \%$ aluminum, porosity was not completely eliminated, although it was significantly reduced.

High levels of porosity in the pressureless-sintered compacts occurred because (1) at temperatures required for densification (wetting), chemical reaction rates are faster than the spreading

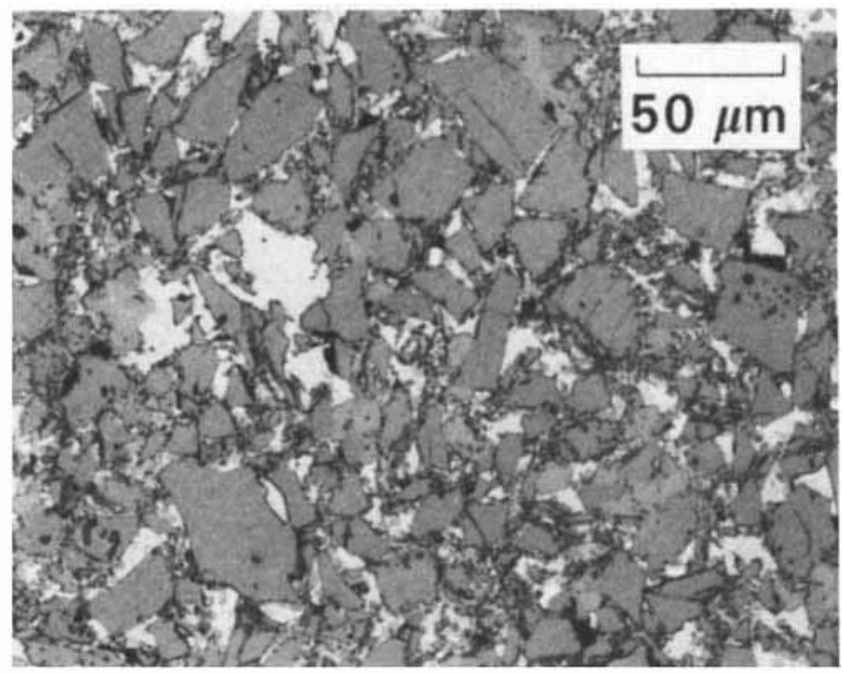

Fig. 5. $\mathrm{B}_{4} \mathrm{C}-\mathrm{Al}(30 \mathrm{vol} \%)$ cermet initially sintered at $1180^{\circ} \mathrm{C}$ for 2 min under vacuum $\left(10^{-3} \mathrm{~Pa}\right)$ and subsequently hot isostatically pressed at $1000^{\circ} \mathrm{C}$ for $30 \mathrm{~min}$ at $207-\mathrm{MPa}(\approx 30000$-psi) argon. Note improvement in uniformity compared with Fig. 4. 
Table III. Processing Trade-offs for $\mathrm{B}_{4} \mathrm{C}-\mathrm{Al}$ Cermets

\begin{tabular}{|c|c|c|c|}
\hline Processing trade-off & $\begin{array}{l}\text { Parameters that } \\
\text { control trade-off }\end{array}$ & $\begin{array}{l}\text { Effect of trade-off } \\
\text { on reactive-liquid } \\
\text { sintering mechanism }\end{array}$ & Optimum processing \\
\hline Wetting versus evaporation & $\begin{array}{l}\text { High temperature versus } \\
\text { low temperature }\end{array}$ & $\begin{array}{l}\text { Depletion of liquid aluminum } \\
\text { by evaporation }\end{array}$ & $\begin{array}{l}\text { Use high temperatures } \\
\text { for short times }\end{array}$ \\
\hline $\begin{array}{l}\text { Chemical reaction versus } \\
\text { densification }\end{array}$ & $\begin{array}{l}\text { Short time versus } \\
\text { long time }\end{array}$ & $\begin{array}{l}\text { Chemical reaction kinetics } \\
\text { faster than densification } \\
\text { kinetics results in } \\
\text { inhibiting rearrangement and } \\
\text { depletion of aluminum due to } \\
\text { new phase formation }\end{array}$ & $\begin{array}{l}\text { Speed up densification rate } \\
\text { by applying pressure } \\
\text { and/or slow down } \\
\text { chemical reaction rate by } \\
\text { increasing } \mathrm{B}_{4} \mathrm{C} \text { grain size }\end{array}$ \\
\hline $\begin{array}{l}\text { Axial pressure versus } \\
\text { isostatic pressure }\end{array}$ & $\begin{array}{l}\text { Hot-pressing versus } \\
\text { hot isostatic pressing }\end{array}$ & $\begin{array}{l}\text { Stress gradients } \\
\text { inhibit rearrangement }\end{array}$ & $\begin{array}{l}\text { Hot isostatic pressed } \\
\text { presintered compacts }\end{array}$ \\
\hline
\end{tabular}

rates for aluminum, and (2) at these temperatures, the vapor pressure for aluminum is higher than that of the vacuum-processing environment employed. Both of these mechanisms result in the depletion of aluminum. The formation of new phases (reaction kinetics), however, has the most detrimental effect. When enough reaction product has formed, the microstructure becomes "locked up," prohibiting further rearrangement. This, combined with the fact that there is an insufficient amount of molten aluminum to fill the remaining pores, results in high-porosity final products.

Table I shows the results of the vacuum-hot-pressed compacts. These results indicate that increasing the aluminum content does reduce the amount of porosity in the cermet. Also, increasing the pressure (while lowering the hot-pressing temperature to slow down the depletion of aluminum) reduced, but did not eliminate, porosity completely.

Densification by hot-pressing is inhibited by mechanisms other than the competition between phase formation and the capillary flow of molten aluminum. Figure 4 shows regions where local densification is obtained by satisfying the capillaritythermodynamic criterion of low contact angles, while grossly porous regions are sporadically located adjacent to these dense regions. Agglomeration of the $\mathrm{B}_{4} \mathrm{C}$ particles will also increase this effect.

Axial forces applied to powders during vacuum hot-pressing in a graphite die result in radial forces on the compact. The magnitude of these radial forces is largely dependent on the plasticity of the powders and always results in stress-concentration gradients within the compact. ${ }^{33}$ When $\mathrm{B}_{4} \mathrm{C}$ grains are forced to bridge or lock tightly in regions of high-stress concentrations, liquid rearrangement by capillary action will be hindered. This will permit local densification where rearrangement is possible (low-stress concentration areas within the compact), resulting in aluminumdepleted regions where bridging is the strongest.

Since we desired to achieve densification without depleting aluminum and also avoid the previously described mechanisms inhibiting uniform rearrangement, we hot isostatic pressed presintered compacts. (The presintered compacts were sealed under vacuum in stainless-steel cans.)

Table II shows the results of the hot isostatic pressed compacts. Even with hot isostatic pressing, however, the results indicate that a minimum amount of aluminum is required to reduce porosity to negligible levels ( $\leq 1.0 \mathrm{vol} \%$ ). Hot isostatic pressed, presintered compacts had connected porosities $\leq 3.5$ vol\%, whereas nonpresintered (nonwetted) compacts had porosities in excess of 10 vol\%. As aluminum content was increased above $30 \mathrm{vol} \%$, connected porosities dropped to below 1 vol\%. A hot isostatic pressed microstructure is shown in Fig. 5. The microstructure confirms that the uniform application of pressure resulted in (1) accelerating the densification kinetics faster than the chemical reaction kinetics and (2) elimination of stress-induced microstructural inhomogeneities.

Our study has shown that certain processing trade-offs must be considered to produce $\mathrm{B}_{4} \mathrm{C}-\mathrm{Al}$ composites. Table III summarizes these trade-offs.

\section{Conclusions}

Based on fundamental capillarity thermodynamics, reaction thermodynamics, and densification kinetics, definite processing criteria have been established for obtaining $\mathrm{B}_{4} \mathrm{C}-\mathrm{Al}$ composites. In these materials, chemical reactions occur between $800^{\circ}$ and $1400^{\circ} \mathrm{C}$. These interfacial reactions are the driving force for the wetting of $\mathrm{B}_{4} \mathrm{C}$ by molten aluminum. Because the chemical reactions cannot be eliminated, it is necessary to process $\mathrm{B}_{4} \mathrm{C}-\mathrm{Al}$ by rapidly heating to near $1200^{\circ} \mathrm{C}$ (to ensure wetting) and subsequently heat-treating below $1200^{\circ} \mathrm{C}$ (for microstructural development). Densification is inhibited because chemical reactions occur faster than capillarity-induced liquid rearrangement. Therefore, it is recessary to apply pressure to accelerate densification faster than the kinetics of phase formation, which is the major hindrance o r irrangement during pressureless sintering. To ensure microuly homogeneity, it is also necessary to apply this pressi:. $\therefore$ miform manner by hot isostatic pressing presintered compacts.

\section{References}

'A. Lipp, "Boron Carbide: Production, Properties, Applications" (in Ger.), Tech. Rundsch., 57 [14] 5 (1965); 57 [28] 14 (1965); 57 [33] 3 (1965); 58 [7] 3 (1966).

${ }^{2} \mathrm{G}$. de With "High-Temperature Fracture of Boron Carbide: Experiments and Simple Theoretical Models," J. Mater. Sci., 19, 457-66 (1984).

${ }^{3}$ S. Prochazka and S. L. Dole, "Development of Spacecraft Materials and Structures Fundamentals," Rept. No. SRD-85-021, General Electric Company Corporate Research and Development, Schenectady, NY, 1985.

${ }^{4} \mathrm{M}$. Beauvy and R. Angers, "Mechanisms of Hot-Pressing of Boron Carbide Powders"; pp. 279-86 in Science of Ceramics, Vol. 10. Edited by H. Hausner. Deutsche Keramische Gessellschaft, Weiden, FRG, 1980.

5J A. Cornie, R. Suplinskas, and A. Hauze "Boron-Aluminum Composites"; p. 28 in Proceedings of Advanced Fibers and Composites for Elevated Temperap. 28 in Proceedings of Advanced Fibers and Composites for Elevated Tempera-
tures. Edited by I. Ahmad and B. R. Noton. The Metallurgical Society of AIME, tures. Edited by I. Ahm

${ }^{6}$ S. D. Karmarkar and A. P. Divecha, "Fabrication and Properties of Boron Carbide-Reinforced Aluminum Composites," NSWC TR 84-160. Naval Surface Weapons Center, Dahlgren, VA, 1984.

'P. R. Roy and C. Ganguly, "Dispersion-Type Composites for Nuclear Reactors"; pp. 159-79 in Sintered Metal-Ceramic Composites. Edited by G.S. Upadhaya. Elsevier, Amsterdam, Netherlands, 1984.

${ }^{8}$ J. E. Smugeresky, H. J. Rack, and G. B. Brasell, "Development of a NonVolatile Boron Carbide-Copper Cermet Neutron Shield for High-Performance Shipping Casks," SAND-80-0802C, Sandia National Laboratories, Alburquerque, NM, 198

${ }^{9}$ I. A. Aksay, C. E. Hoge, and J. A. Pask, "Wetting under Chemical Equilibrium and Nonequilibrium Conditions," $J$. Phys. Chem., 78, 1178-83 (1974).

${ }^{10} \mathrm{C}$. R. Manning and T. B. Gurganus, "Wetting of Binary Aluminum Alloys in Contact with Be, B, C, and Graphite," J. Am. Ceram. Soc. 52 [3] 115-18 (1969)

Contact with Be, $\mathrm{B}_{4} \mathrm{C}$, and Graphite," Am. Ceram. SoC., 52 [3] 115-18 (1969).
"A. D. Panasyuk and T. V. Dubovik, "Wetting of Boron Carbide System Samples "A. D. Panasyuk and T. V. Dubovik, "Wetting of Boron Carbide System Samples
with Molten Metals" (in Russ.), Dielektriki (Dieletr. Poluprovodn.), 2, 120-25 (1972).

${ }^{12} \mathrm{G}$. A. Kolesnichenko, "Wettability of Refractory Covalent Crystals by Metallic Melts" (in Russ.), Smachivaemost Poverkn. Svoistva Rasplavov Tverd. Tel. 1972, 71-74.

${ }^{13}$ A. D. Panasyuk, V. D. Oreshkin, and V. R. Maslennikova, "Kinetics of the Reactions of Boron Carbide with Liquid Aluminum, Silicon, Nickel, and Iron," Sov. Powder Metall. Met. Ceram. (Engl. Transl.), 18 [7] 487-90 (1979).

${ }^{14}$ A. D. Panasyuk, V. R. Maslennikova, and E. V. Marek, "Reactions of Materials of the $\mathrm{B}_{4} \mathrm{C}-\mathrm{Cr}$ System with Liquid Metals," Sov. Powder Metall. Met. Ceram. (Engl. Transl.), 20 [10] 729-32 (1982).

${ }^{15}$ M. W. Lindley and G. E. Gazza, "Some New Potential Ceramic-Metal Armor 
Materials Fabricated by Liquid Metal Infiltration," AD-769742, Army Materials and Mechanies Research Center, Watertown, MA, 1973.

${ }^{16}$ J. A. Kohn, G. Katz, and A. A. Giardini, " $A 1 B_{10}$, a New Phase, and a Critique on Aluminum Borides," Z. Kristallogr., 111, 53-62 (1958).

${ }^{17}$ V. I. Matkovich, J. Economy, and R. F. Giese, Jr., "Presence of Carbon in Aluminum Borides," J. Am. Chem. Soc., 86, 2337-40 (1964)

${ }^{18}$ V. I. Matkovich, R. F. Giese, Jr., and J. Economy, "Phases and Twinning in $\mathrm{C}_{2} \mathrm{Al}_{3} \mathrm{~B}_{48}$ (beta $\mathrm{AlB}_{12}$ )," Z. Kristallogr., 122, 108-15 (1965).

${ }^{19} \mathrm{~A}$. Lipp and M. Röder, "On the Subject of Aluminum-Containing Boron Carbides" (in Ger.), Z. Anorg. Allg. Chem., 343, 1-5 (1966) (translated by Leo Kanner Associates, Redwood City, CA, 1971).

${ }^{20}$ R. F. Giese, Jr., J. Economy, and V. I. Matkovich, "Topotactic Transition in $\mathrm{C}_{4} \mathrm{AlB}_{24}$, Acta Crystallogr., 20,697-98 (1966)

${ }^{21} \mathrm{G}$. Bliznakov, P. Peshev, and T. Niemyski, "On the Preparation of Crystalline Aluminum Borides by a Vapour Deposition Process," J. Less-Common Met., 12 $405-10(1967)$.

${ }^{22} \mathrm{E}$. L. Muetterties, The Chemistry of Boron and Its Compounds; pp. 84-90. Wiley, New York, 1967

${ }^{23} \mathrm{G}$. Will, "The Crystal Structure of $\mathrm{C}_{4} \mathrm{AlB}_{24}$ " Acta Crystallogr, , Sect. B: Struct. Crystallogr. Cryst. Chem., B25, 1219-22 (1969) (translated by Lawrence Livermore National Laboratory, Livermore, CA, UCRL TRANS-11966, 1984).

${ }_{24}$ A. J. Perrotta, W. D. Townes, and J. A. Potenza, "Crystal Structure of $\mathrm{C}_{8} \mathrm{Al}_{2.1} \mathrm{~B}_{51}, "$ Acta Crystallogr., Sect. B: Struct. Crystallogr. Cryst. Chem., B25, $1223-29(1969)$
${ }^{25} \mathrm{H}$. Neidhard, R. Mattes, and H. Becher, "The Production and Structure of a Boron Carbide Containing Aluminum," Acta Crystallogr., Sect. B: Struct. Crystallogr. Cryst. Chem., B26, 315-17 (1970) (translated by Lawrence Livermore National Laboratory, Livermore, CA, UCRL TRANS-11965, 1984).

${ }^{26} \mathrm{G}$. Will, "On the Existence of AlB ${ }_{10}$ : A Critical Review of the Crystal Struc${ }^{26} \mathrm{G}$. Will, "On the Existence of $\mathrm{AlB}_{10}$; A Critical Review of the
teres of $\mathrm{AlB}_{10}$ and $\mathrm{C}_{4} \mathrm{AlB}_{24}$, " Electron Technol., 3, 119-26 (1970).

${ }_{27}$ G. V. Samsonov, V. A. Neronov, and L. K. Lamikhov, "The Conditions, Struc-
${ }_{10}$. Sald $\mathrm{C}_{4} \mathrm{AlB}_{24}$, Electron Technol, 3, 119-26 (1970). ture, and Some Properties of Phases in the Al-B System," J. Less-Common Met., 67, 291-96 (1979)

${ }^{28 \mathrm{Z}}$. Inouhe, H. Tanaka, and Y. Inomata, "Synthesis and X-ray Crystallography of Aluminum Boron Carbide, $\mathrm{Al}_{8} \mathrm{~B}_{4} \mathrm{C}_{7}$," J. Mater. Sci., 15, 3036-40 (1980).

${ }^{29}$ M. L. Wilkins, C. F. Cline, and C. A. Honodel, "Light Amor," UCRL-71817, Lawrence Livermore National Laboratory, Livermore, CA, 1969.

${ }^{30}$ Powder Diffraction File, Card No. Joint Committee on Powder Diffraction
Patere ${ }^{30}$ Powder Diffraction File, Card
Standards, Swarthmore, PA, 1985

${ }^{31}$ D. C. Halverson, A. J. Pyzik, and I. A. Aksay, "Boron-Carbide-Aluminum and Boron-Carbide-Reactive Metal Cermets," U.S. Pat. No. 4605440, Aug. 12, 1986.

${ }^{32}$ M. Sarikaya, T. Laoui, D. L. Milius, and I. A. Aksay, "Identification of a New Phase in the Al-B-C Ternary By High-Resolution Transmission Electron Microscopy"; pp. 168-69 in Proceedings of the 45th Annual Meeting of the Electron Microscopy Society of America. Edited by G. W. Bailey. San Francisco Press, San croscopy Society of

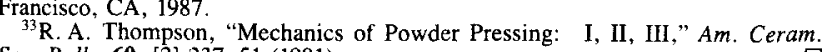
Soc. Bull., 60, [2] 237-51 (1981).

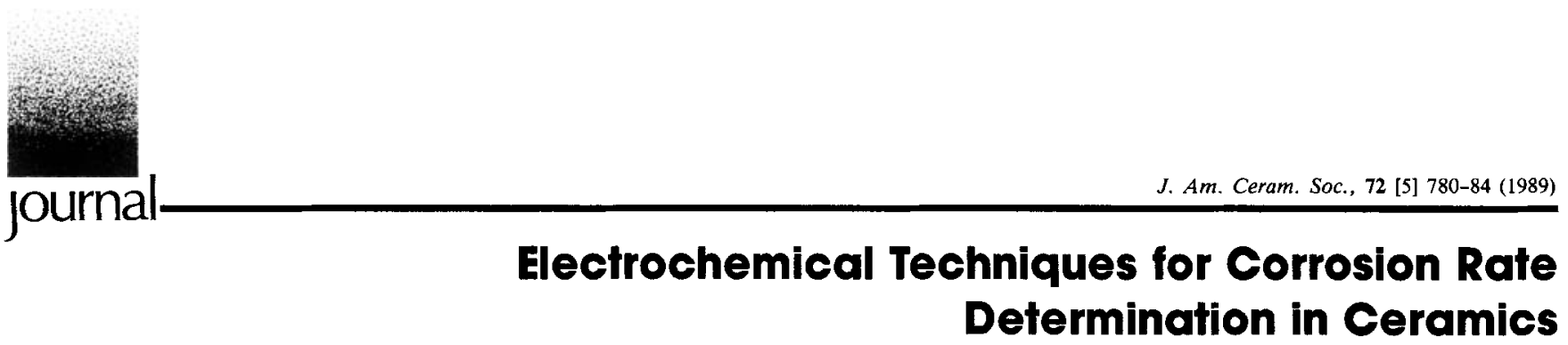

\author{
Ramesh Divakar, ${ }^{*}$ Srinvasa G. Seshadri, ${ }^{*}$ and Makuteswara Srinivasan*
}

Technology Division, Standard Oil Engineered Materials Company, Niagara Falls, New York 14302

\begin{abstract}
Standard electrochemical test procedures have been successfully applied to determine the corrosion rates of $\mathrm{SiC}$-based ceramics in aqueous reagents. Direct-current polarization measurements in $\mathrm{HCl}$ solutions indicate that the corrosion rate of $\alpha-\mathrm{SiC}$ is $0.0050 \pm 0.0002 \mathrm{mil} / \mathrm{yr}$ and is fairly independent of $\mathrm{HCl}$ concentration. The corrosion rates of $\alpha$-SiC are significantly lower than those for reaction-sintered SiC in all of the electrolytes used including $\mathrm{HCl}, \mathrm{HNO}_{3}, \mathrm{H}_{3} \mathrm{PO}_{4}$, and aqua regia. It is believed that the free $\mathrm{Si}$ contained in the reaction-sintered $\mathrm{SiC}$ is responsible for the higher corrosion rates. It has been shown that electrochemical techniques are reproducible and eminently suitable for determining very low corrosion rates encountered in ceramics. [Key words: silicon carbide, electrochemistry, corrosion, electrical properties, polarization.]
\end{abstract}

\section{Introduction}

A COMMON application of the high-performance ceramics, such as silicon carbide, is in the chemical processing industry where acids, alkali, and other combinations of corrosive fluids are pumped, requiring corrosion and wear-resistant seals. ' Although the corrosion rates of ceramics are generally small compared to the metallic components, the corrosion behavior of potential seal

J. L. Smialek - contributing editor

Manuscript No. 199103. Received June 6, 1988; approved October 4, 1988. Presented at the 89 th Annual Meeting of the American Ceramic Society, Pittsburgh, PA (Engineering Ceramics Division, Paper No. 62-C-87).

* Member, American Ceramic Society. materials is not well documented in various reagents or combinations of liquids that may be encountered in service.

In the past, the corrosion rates of ceramics have been determined mostly by periodic weight loss measurements after immersion in the electrolyte of interest, but the applicability of this method to extremely low corrosive conditions is very limited. Furthermore, prolonged test periods are needed (over $200 \mathrm{~h}$ ) for reasonable accuracy in weight loss measurements. Therefore, the development of a comprehensive data base on corrosion rates of various ceramics in different reagents at temperatures of interest is a laborious task. This technique, however, is simple and straightforward and does not require any knowledge of corrosion reactions that are occurring.

The electrochemical techniques, on the other hand, offer a potentially easier and quicker way to determine the corrosion rates. The basis for this approach lies in the implicit understanding of the chemical reactions that are responsible for corrosion. In addition, appropriate electrochemical theories and analysis procedures need to be developed to reduce the current and voltage observations to corrosion rate information. Many different procedures utilizing dc and ac techniques have been evolved in recent years, ${ }^{2-5}$ each providing a wealth of information on the corrosion phenomena for metals and alloys. With improved instrumentation and analysis, these methods have become very practical.

A survey of the corrosion literature reveals that, except for a cursory study, ${ }^{6}$ there has been very little work done in the area of electrochemical corrosion of ceramics. In this work, an attempt is made to evaluate the applicability of these techniques to two SiCbased ceramics in various aqueous reagents. This work is also aimed at the development of electrochemical test procedures for ceramics and ceramic composites since no standards are available 